\author{
УКРАÏHСЬКА АРХITEКTУРA \\ ЯК ПРЕДМЕТ ДОСЛІДЖЕННЯ У \\ ПРАЦЯХ ВІТЧИЗНЯНИХ НАУКОВЦІВ \\ 1900-X POKIB \\ Ірина Удріс, \\ https://orcid.org/0000-0002-7205-1566 \\ кандидат мистецтвознавства, \\ профессор, \\ Криворізький державний педагогічний \\ університет, \\ Кривий Ріг, Україна \\ e-mail: sudris@i.ua

\section{UKRAINIAN ARCHITECTURE AS A SUBJECT OF RESEARCH IN THE WORKS OF DOMESTIC} \\ SCIENTISTS OF THE $1900 \mathrm{~S}$

\section{Iryna Udris,} \\ https://orcid.org/0000-0002-7205-1566 \\ $\mathrm{PhD}$ in Art Studies, \\ Professor, \\ Kryvyi Rih State \\ Pedagogical University, \\ Kryvyi Rih, Ukraine \\ sudris@i.ua
}

\section{Анотація}

Мета дослідження полягає у виявленні внеску представників українського мистецтвознавства 1900-х рр. у справу визначення національних форм вітчизняної архітектури. Методологія дослідження базується на використанні комбінованого тематико-хронологічного підходу; опис публікацій поєднується з компаративним та порівняльним аналізами. Наукова новизна статті полягає у висвітленні початкової стадії формування уявлень про унікальні риси української архітектури в контексті суспільного запиту і провідних тенденцій загального художнього процесу зазначеного періоду. Окреслено чинники зростання уваги науковців вказаного десятиріччя до системного вивчення споруд України від найдавніших часів до XIX ст., зокрема, дерев'яних культових. Охарактеризовано праці відомих фахівців тих років: Г. Павлуцького, Є. Рєдіна, О. Новицького, В. Щербаківського, М. Макаренка, Є. Сіцінського та інших авторів. Вивчення названої проблеми в цих наукових роботах засновано на аналізі численної інформації як результату системної роботи багатьох науковців й аматорів з дослідження творів архітектури. Визначено наукові ідеї дослідників щодо еволюції форм даної галузі образотворчості та обґрунтування унікальності української архітектури. Висновки. Аналіз численної кількості першоджерел наукових публікацій дозволяє

\section{Abstract}

The purpose of the study is to identify the contribution of representatives of Ukrainian art history in the 1900s to the definition of national forms of national architecture. The research methodology is based on the use of combined, thematic and chronological approaches; description of publications is combined with comparative and comparative analyzes. The scientific novelty of the article is to highlight the initial stage of formation of ideas about the unique features of Ukrainian architecture in the context of public demand and the leading trends of the general artistic process of this period. The factors of growing attention of scientists of the specified decade to the systematic study of buildings of Ukraine from ancient times to the XIX century, in particular, wooden cult. The works of famous specialists of those years are described: G. Pavlutsky, E. Redin, O. Novitsky, V. Shcherbakovsky, M. Makarenko, E. Sitsinsky and other authors. The study of this problem in these scientific works is based on the analysis of numerous information as a result of systematic work of many scientists and amateurs on the study of architectural works. Researchers' scientific ideas on the evolution of forms of this field of art and substantiation of the uniqueness of Ukrainian architecture are determined. Conclusions. Analysis of numerous sources of scientific publications allows us 
зробити висновок, що впродовж 1900-х рр. відбулося становлення концепції своєрідності національних архітектурних форм на всіх історичних етапах. Наукова аналітика характерних ознак українських архітектурних пам'яток різних періодів здійснювалася в ракурсі взаємозв'язків з мурованим зодчеством та з відповідними рішеннями інших історико-національних архітектурних шкіл. Історію української науки про мистецтво означеного десятиліття можна розглядати як історію ідей про національні форми образотворчості та архітектури. Провідна ідея унікальності української архітектури спрямувала і стала підґрунтям розвитку української науки про мистецтво в наступних десятиріччях.

\section{Ключові слова:}

національний романтизм, стиль, архітектура, дерев'яні споруди, муроване будівництво, чинники, провідні ознаки, конструктивні форми. to conclude that during the 1900's there was a concept of originality of national architectural forms at all historical stages. Scientific analysis of the characteristic features of Ukrainian architectural monuments of different periods was carried out in the perspective of the relationship with the masonry architecture and the relevant decisions of other historical and national architectural schools. The history of Ukrainian science of art of this decade can be considered as the history of ideas about national forms of art and architecture. The leading idea of the uniqueness of Ukrainian architecture directed and became the basis for the development of Ukrainian art science in the following decades.

\section{Key words:}

national romanticism, style, architecture, wooden buildings, brick construction, factors, leading features, constructive forms.
Вступ 10 Однією з провідних проблем розбудови нашого сучасного суспільства є повноцінний розвиток різних напрямків національної культури на основі освоєння її вікових традицій. Зокрема, вагомого значення набуває вивчення шляхів розвитку національних наукових шкіл, а кожна галузь наукового знання потребує систематизації та оцінки на сучасному рівні власних досягнень. У сфері українського образотворчого мистецтва й мистецтвознавства зростає актуальність проблеми поглибленої розробки історії вітчизняної науки, формування в їі межах окремих напрямків досліджень, вивчення досвіду фахівців минулого, в тому числі - доробку науковців початку XX ст. у питаннях виявлення національних форм української образотворчості.

\section{Мета дослідження

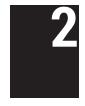

Мета даної статті - дослідити внесок вітчизняного мистецтвознавства 1900-х рр. у дослідження архітектурних споруд України та розкрити значущість наукових праць того періоду у визначенні національних форм української архітектури в контексті міжнародного художнього процесу.

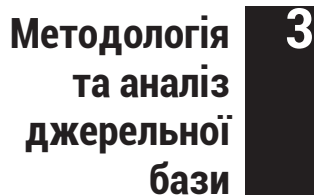

В останні роки солідна наукова спадщина фахівців означеної доби у сфері вивчення національного образотворчого мистецтва привертає все більшу увагу науковців. У загальному контексті досліджень, що стосуються українського мисте- 
цтва означеної доби, мистецтвознавчі публікації кін. XIX - поч. XX ст. висвітлюються у працях Р. Захарчук-Чугай, В. Овсійчука, Л. Соколюк, Т. Кара-Васильєвої, М. Селівачова, А. Тарасенко, Р. Шмагало. Досягнення вітчизняних науковців тих років розглядаються в публікаціях С. Білоконя, І. Голода, Д. Степовика, В. Ульяновського, В. Яцюка, В. Ханка, В. Пуцка, О. Мандебури-Ноги, М. Криволапова, Є. Шудрі, Ю. Смолія, С. Міщука, І. Старенького та інших.

Вагомим внеском у вітчизняну історію науки про мистецтво, передусім у становлення уявлень про український стиль, стала грунтовна праця О. Ноги (1997). У книзі С. Побожія (2005) висвітлюється наукова спадщина представників харківської школи мистецтвознавства: Є. Рєдіна, М. Сумцова, Ф. Шміта, С. Таранушенка та інших. Помітним явищем у справі дослідження витоків формування вітчизняного мистецтвознавства слід вважати фундаментальну працю М. Палієнко (2005a, 2005b, 2005c), присвячену журналу «Кіевская старина». У ї̈ трьох частинах розглянуто роль часопису у науковому та громадському житті країни кінця означеної доби та містяться систематичний і хронологічний покажчики змісту видання за всі роки існування. Вагомістю висвітлення означеної проблеми є монографія Н. Ковпаненко (2013), присвячена вивченню архітектурно-мистецької спадщини Наддніпрянської України у вітчизняних історичних дослідженнях кінця XIX - початку XX ст. У науковій праці з'ясовуються провідні напрямки становлення знань про мистецтво в процесі розвитку історичної науки. Значну наукову цінність становлять огляди доробку дослідників початку XX ст. у публікаціях А. Пучкова. Зокрема, вчений докладно характеризує доробок Г. Павлуцького в передмові до видання його праці про дерев'яні та муровані храми України (Пучков, 2017). Разом з тим, проблема не втрачає актуальності, в тому числі стосовно висвітлення досягнень окремих етапів становлення науки.

3 огляду на трактування праць окресленої доби в якості явищ, детермінованих тогочасними соціокультурними умовами та світоглядними позиціями вчених, написання статті базується на використанні комбінованого, тематико-хронологічного підходу. В роботі поєднується опис публікацій з компаративним та порівняльним аналізами.

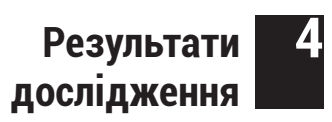

Процес формування наукового мистецтвознавства в Україні охоплює близько половини століття - від 1870-х до 1920-х рр. і в основних параметрах тісно пов'язаний з розвитком суспільного життя країни, різних галузей науки та культури. Активізація зусиль українського суспільства в справі пізнання власної історії, етнографії, мови, літератури і мистецтва сприяє становленню науки про мистецтво. З огляду на історичні, соціально-політичні, 
економічні та культурні умови, на території України в той період формуються дві наукові і художні школи - київська та львівська, при постійному прагненні національної інтелігенції до взаємозв'язків. На українських землях у складі Російської імперії особливе місце в процесі активного освоєння власного мистецького минулого належало Києву, навколо якого згуртовувались науковці різних міст - Харкова, Полтави, Одеси тощо.

Характерною ознакою періоду становлення науки був певний універсалізм зацікавлень, коли науковці прагнули висвітлити найрізноманітніші питання, виявити себе в дослідженні різних видів образотворчості, опираючись на провідні тогочасні наукові ідеї, теорії та методи даної галузі гуманітарних знань. Основоположним завданням стало формування наукових уявлень про національні форми нашого мистецтва на кожному з етапів еволюції. Серед низки чинників, що безпосередньо вплинули на розвиток нової наукової галузі, були: викладання історії мистецтва у вищих навчальних закладах країни, діяльність наукових установ і об'єднань фахового спрямування за активної участі ряду земств, вивчення пам'яток образотворчості археологічною наукою, чвертьвікове функціонування часопису «Киевская старина» тощо.

Помітну роль у процесах тогочасного вітчизняного й міжнародного мистецького життя відігравав власне художній фактор. Як відомо, середина XIX ст. характеризувалась зміною стадій розвитку світового мистецтва від Нового до Новітнього часу. Митці тих десятиліть проводили «ревізію» загальної художньої спадщини з метою визначення подальших шляхів розвитку образотворчості. Зокрема, в архітектурі і прикладному мистецтві спостерігається розмаїття «ретроспективного історизму». Так, захоплення англійців готикою призвело до ії ототожнення в країні з національним стилем; у Франції певним джерелом натхнення стало рококо; в ряді країн спостерігається звернення до етнографізму.

Окреслені явища позначаються на процесі формування першого в історії мистецтва, свідомо твореного зусиллями митців різних країн «універсального» стилю, єдиного для всіх елементів навколишнього середовища - ар-нуво. При цьому спостерігається тенденція до формування національно виразних художніх напрямків, що засвідчує розмаїття термінів, якими означається цей стиль у різних країнах (модерн, сецесія тощо). У фаховій літературі розглядаються варіанти класифікації творів ар-нуво (Лагутенко, 2006). Зокрема, можна виділити «флореальний», «геометричний» та «національно-романтичний» варіанти стилю. І якщо в Англії, Франції чи Німеччині ставили за мету повне стилістичне оновлення мистецтва, що відбилось і у 
визначенні «Нове мистецтво», то для Польщі, Чехії та України «нове» ототожнилось з «національним» (Ханко, 1997).

Представники національного романтизму в мистецтві ар-нуво прагнули до створення національних напрямків та спиралися в цьому на дух і стилістику народного мистецтва. Таким шляхом йшов розвиток образотворчості групи країн Північної та Східної Європи. В цьому ж руслі формується мистецтво ар-нуво в Україні. У нашій країні відчутно переважає національно-романтична течія, в руслі якої працюють і художники-практики, і теоретики та історики мистецтва. Сказане дає підстави розглядати розмаїті прояви пошуків національного стилю в українському мистецтві та мистецтвознавстві як конкретний вияв загальноєвропейської тенденції, складову міжнародного мистецького процесу.

Прагнення сформулювати чіткі ознаки українського стилю в контексті реалізації ідей національного романтизму стало вагомим чинником розвитку науки про мистецтво. Завдяки зусиллям українських дослідників 1870-х - 1890-х рр. були закладені основи нової галузі гуманітарного знання. Численні зібрані й оприлюднені матеріали беззаперечно доводили історичну самобутність української культури в цілому та їі образотворчості. Наукове обґрунтування цієї ідеї стимулювало спеціальні дослідження початку XX ст. у даній сфері. Серед них чільне місце займало дослідження національних архітектурних форм.

Архітектура віддавна сприймалась в теорії та історії мистецтва, в культурологічних та естетичних дослідженнях як універсальний вид образотворчості, вивченню якої приділялась провідна увага. Вагому роль у постановці та розв'язанні питань у даній сфері протягом багатьох років відігравали Всеросійські Археологічні з"ізди - передусім ті, що проводились на території України. Аналіз матеріалів з"іздів XIX ст. дає підстави констатувати, що на першому етапі становлення дослідників цікавили пам'ятки великокнязівських часів. Розглядались вони у контексті розвитку візантійської художньої системи; разом з тим, вже з перших кроків виявлялось прагнення визначити відмінні риси, притаманні вітчизняним спорудам. Ця думка простежується у публікаціях «Про святу Софію Київську» і «КиєвоМихайлівський золотоверхий монастир» П. Лебединцева (1878, 1885), «Київська архітектура X - XII століть» та «Церковно-археологічні нариси, дослідження та реферати» П. Лашкарьова (Лашкарев, 1875, 1898), «Історико-топографічні нариси давнього Києва (за планом давнього Києва 1638 року)» М. Петрова (1897), публікації М. Константиновича (1896) про Юрієвську Божницю у «Київській старовині» тощо.

Свідоцтвом наукового визнання своєрідності форм української архітектури та необхідності їх системного дослідження 
стало порушене під час проведення Київського Археологічного з'ізду 1899 р. питання про формування на базі Київського історичного товариства Нестора-літописця Комісії з опису і вивчення пам'яток місцевої старовини, якій доручено було дослідити й описати пам'ятки Київської, Подільської, Волинської, Чернігівської та Полтавської губерній ("Заседание обществ", 1899). У результаті активної роботи було зібрано гігантський фактологічний матеріал, що ліг в основу наукових видань і подальших досліджень відомих фахівців. Активізації дослідницької діяльності сприяло й зростання соціокультурного запиту щодо визначення й опрацювання національного стилю в художній практиці доби.

Найважливішим у контексті діяльності комісії стало поширення параметрів дослідницької роботи як у типологічному, так і в хронологічному напрямках. До вивчення залучаються пам'ятки дерев'яного і мурованого сакрального і цивільного будівництва від часів прийняття християнства і до кінця XVIII ст. Як і в XIX ст., у1900-х рр. найпомітніші дослідження у цій галузі пов'язані з археологічними з'іздами. Так, Є. Рєдін (Редин, 1905) у контексті підготовки до зібрання 1902 р. оприлюднює матеріали до вивчення церковних старожитностей України, зокрема церков м. Харкова. У роботі розглядаються й архітектурні рішення, й оздоблення та речі церковного вжитку низки харківських храмів. Серед іншого автор стверджує, що дерев'яна сакральна архітектура Харкова, - а перші церкви, за його переконанням, всі були дерев'яними, - не мала нічого спільного з російською архітектурою. Натомість, у ній спостерігаються риси спорідненості з храмами Полтавської, Катеринославської губерній та Галичини (Редин, 1905, с. 4).

Актуальні підходи до висвітлення й оцінювання національних пам'яток виявились у капітальній праці Г. Павлуцького «Старожитності України. Дерев'яні та кам'яні храми України», виданій напередодні XIII Археологічного з'їзду, що проходив у 1905 р. у Катеринославі (Павлуцкий, 1905). Вчений був одним зі співробітників згаданої Комісії, до складу якої входили й активно збирали інформацію В. Щербина, І. Каманін, В. Щербаківський, Є. Сецинський, О. Левицький та інші науковці. Зокрема, В. Щербаківський сфотографував і описав майже 400 українських дерев'яних церков, що з вдячністю відмітив Г. Павлуцький, якому було доручено підготувати до видання нагромаджений матеріал.

Праця складається з вступної статті про давню українську культову архітектуру та опису окремих пам'яток з їх видами і планами. У вступній статті ґрунтовно досліджується ґенеза дерев'яних та мурованих сакральних церков. Автор подає загальну характеристику форм давніх вітчизняних храмових споруд, планування, конструктивних рішень, будівельних прийомів, що 
використовувались при спорудженні дерев'яних церков. Вчений проводить порівняльний аналіз храмів російської Півночі та України і доходить висновку, що основний принцип українських дерев'яних церков полягає у підпорядкуванні всіх частин єдиному цілому, тоді як російські споруди тяжіють до самостійного значення кожної деталі (Павлуцкий, 1905, с. 12). Порівняння українських храмів з європейськими, зокрема сілезькими, теж дає авторові підстави для ствердження самобутності наших пам'яток. Характерно, що в тому ж році у петербурзькій та московській періодиці з'являються статті «Малоросійське церковне зодчество» В. Карповича (1905) та «Спадщина України» М. Філянського (Филянский, 1905) аналогічного спрямування.

Співпраця в Комісії на багато років визначила пріоритетний напрямок дослідницької діяльності В. Щербаківського. Ще в 1904 р. з'являється його стаття пошуково-інформаційного характеру, присвячена типам старовинних українських сакральних споруд (Щербаковский, 1904). Через два роки в ґрунтовній публікації вчений значною мірою розв'язує проблему систематизації й узагальнення матеріалу (Щербаковський, 1906). Після визначення типових рис, притаманних усім вітчизняним дерев'яним церквам, автор характеризує їх за групами - від однобанної до дев'ятибанної у залежності від основного конструктивного принципу.

Вибудовуючи схему еволюції конструктивних форм, В. Щербаківський переконує читача, що розвиток ішов від меншого об'єму до більшого шляхом симетричних прибудов до первісного однобанного об'єму наступних частин. Зважаючи на те, що при цьому завжди враховується обов'язкова для української сакральної архітектури спрямованість споруди угору, вчений вважає логічним завершенням вітчизняних конструктивних пошуків дев'ятибанні церкви (Щербаковський, 1906, с. 25). Найбільш розповсюдженим типом дерев'яних церковних споруд в Україні є, на думку автора, трьохбанна церква - найбільш гармонійна і сумірна людині. Звертаючись до архітектурного декору, В. Щербаківський виділяє головки або маківки як характерний елемент і підкреслює, що в національній архітектурі маківка є логічним завершенням бані (Щербаковський, 1906, с. 27). Ця публікація дослідника, як і праця Г. Павлуцького, відіграла провідну роль у подальшому дослідженні архітектурних форм.

На розглянуті роботи посилається Є. Сецинський (Ю.Сіцінський) у своєму огляді південноруського церковного зодчество (Сецинский, 1907). Вагомого значення набуває висловлена автором теза про прагнення вивчати вітчизняну минулу історію і культуру, що зростає на ґрунті соціальних зрушень і потреби національного самовизначення. Конкретна тема розглядається вченим у загальному українознавчому контексті. На питан- 
ня, чи дійсно існує особливий український архітектурний тип храму і де його слід шукати, Є. Сецинський у результаті огляду низки споруд Поділля дає відповідь: це передусім сільські дерев'яні церкви. Як і Г. Павлуцький та В. Щербаківський, науковець переконаний, що вертикальність і зліт угору завдяки продуманій конструктивній системі є відмінною рисою нашої сакральної архітектури. Автор підтримує думку інших дослідників щодо самостійної переробки первісних візантійських мотивів у самобутній стиль. За переконанням автора, українські церкви й у всі пізніші часи виявляють виразну своєрідність.

Зразком детального аналізу конкретного твору, що також завершується вагомими підсумками, є стаття М. Макаренка (1908a, 1908b) з дослідженням роменської Покровської церкви, що зведена, як пише дослідник, у 1764 р. коштом П. Калнишевського. Автор трактує пам'ятку як приклад загальної тенденції в архітектурі часів і території козаччини, про що свідчить і красномовний вступ у славу національного мистецтва, в якому проголошується, що українське життя тих часів ознаменоване загальним потягом до краси, особливо вражаючим з огляду на бурхливі події доби (Макаренко, 1908а, с. 211). У детальному аналізі Покровської церкви акцент зроблено на своєрідній трапецієвидній формі дверних отворів, як формі, «що користується виключним правом громадянства» в українській архітектурі (Макаренко, 1908а, с. 215). Не менш характерною відмінною рисою М. Макаренко вважає контраст напівтемних бічних частин з таємничим світлом центрального зрубу, що стрімко біжить у небесну височінь.

Бажання узагальнити і синтезувати набуті відомості з метою вирішення провідної проблеми - визначення специфічних форм вітчизняної архітектури на різних етапах розвитку - зростає дуже швидкими темпами. Нова тенденція яскраво виявляється в низці праць, оприлюднених на найбільш вагомому в цьому плані Чернігівському з'їді 1908 р., серед яких виділяються роботи Г. Павлуцького та О. Новицького. Зміст дослідження Г. Павлуцького «Про походження форм українського дерев'яного церковного зодчества» можна звести до кількох основних положень, що базуються на аналізі значної кількості не лише архітектурних матеріалів, і й стародавніх літописів, книжкової мініатюри тощо (Павлуцкий, 1911). На початку роботи висловлюються дві гіпотези - про спадкоємність форм дерев'яних сакральних споруд України XV-XVII ст. від домонгольських храмів як принцип безперервності розвитку галузі ще від часів св. Володимира та про панування двох улюблених типів храму: трьохзрубних й п'ятизрубних. В основі форм зрубів наших храмів лежить, як переконаний автор, восьмикутник октагон, генетично пов'язаний з такими, наприклад, споруда- 
ми, як церква Сан-Вітале в Равенні та обумовлений технічними причинами (Павлуцкий, 1911, с. 53). Роздуми щодо походження українських архітектурних форм завершуються характерним висновком щодо співвідношення впливів та самобутності в мистецтві. «Українське мистецтво $є$ творчістю оригінальною, що має національний характер, оскільки воно самостійно опрацювало чужі елементи, візантійські чи західні, які до нього приходили. Ні на заході ні в північній Росії не можна зустрінути жодної церкви, яка могла б бути прийнята за взірець українських церков. Це в своєму роді єдині пам'ятки; чому вони і уявляють самостійний стиль» (Павлуцкий, 1911, с. 54).

Автор переконаний, що розглянуті ним типи сакральних дерев'яних споруд, сформовані в домонгольські часи, настільки відповідали місцевим смакам, що відчутно вплинули і на муровану архітектуру барокової доби (Павлуцкий, 1911, с. 57). Як типовий взірець такої творчості розглядається в роботі церква св. Трійці в Густинському монастирі. 3 кінця ж XVII ст. в Україні - в основному зусиллями І. Мазепи, який багато сприяв тогочасному будівництву - розповсюджується і нехарактерний для вітчизняної сакральної архітектури тип латинської базиліки, як у Лубенському Мгарському монастирі. Однак, як відзначено в завершальних рядках роботи, подібні новації не знищили любові народу до форм дерев'яного сакрального зодчества.

Продовженням теми виявлення форм вітчизняних сакральних споруд стала доповідь О. Новицького на з'ізді про риси самобутності в українському зодчестві (Новицкий, 1911). У роботі О. Новицького увага акцентується на визначенні подальшої еволюції провідних типів, що характеризують саме вітчизняні церкви: трьохбанного та п'ятибанного, які символізують Трійцю та візантійський хрест (Новицкий, 1911, с. 60). У дискусії, що точилася на з'їзді відносно напрямку еволюції форм українських храмів, О. Новицький підтримував думку В. Щербаківського про розвиток від одного до дев'яти зрубів як найвищого щабля національної архітектурної думки у галузі сакральної дерев'яної архітектури. Сам він вважав найбільш досконалими трьохзрубні споруди. «Трьохглавий храм $€$ славою нашого церковного стилю, тому то він є пануючим типом нашої архітектури; більше того, в хвилину українського впливу на Москву, запозичений він і Москвою» (Новицкий, 1911, с. 61). О. Новицький наводить також цікаві факти, що свідчать про вплив нашої дерев'яної архітектури на муровану не лише в Україні, а й у Росії, зокрема на московські храми наришкінської доби: у Філях, Петровсько-Розумовському тощо.

Слід зазначити, що на Чернігівському з"їзді була піднята і уважно, хоча й на досить фрагментарному рівні охарактеризована ще одна важлива тема: муроване будівництво пізньої 
козацької доби. Мова йде про дослідження архітектурно-мистецької спадщини Чернігівщини доби Просвітництва Ф. Горностаєва (Горностаев, 1911), що серед іншого сприяло зростанню зацікавлення науковців різними аспектами даної проблеми.

Праці, оприлюднені фахівцями на XIV Археологічному з'ізді, разом з доробками двох попередніх зібрань, певним чином окреслили подальшу спеціалізацію мистецтвознавчих досліджень. Були визначені особливості конструктивної побудови, планування, будівельних прийомів та архітектурного декору різних типів вітчизняних сакральних дерев'яних споруд. Зросло зацікавлення регіональними особливостями національної архітектури (Волков, 1910). Озвучена наукова концепція щодо національних форм української архітектури отримала надалі успішний розвиток.

У наступному десятиріччі дослідження у галузі архітектури структуруються у трьох напрямках: архітектура старокнязівських часів, мурована архітектура барокової доби та дерев'яна архітектура України. Пам'яткам X-XIII ст., більш ретельно систематизованим і висвітленим, приділяється при цьому вже менше уваги. Центр зацікавлень зміщується убік вивчення дерев'яних і мурованих пам'яток вітчизняної цивільної й сакральної архітектури козацьких часів і над різними аспектами даної проблеми продовжать працювати більшість авторів розглянутих праць. До них у 1910-і рр. додаються прізвища ще цілого ряду фахівців - В. Модзалевського, К. Широцького, Ф. Ернста, Ф. Волкова (Ф. Вовк), М. Шумицького, Д. Щербаківського, Ф. Шміта, Г. Лукомського, що поглиблено досліджували означений напрямок у науці про мистецтво.

\section{Наукова новизна та практична значимість дослідження

5

Наукова новизна статті полягає у висвітленні початкової стадії формування уявлень про унікальні риси української архітектури в контексті суспільного запиту і провідних тенденцій загального художнього процесу зазначеного періоду. Окреслено чинники зростання уваги науковців вказаного десятиріччя до системного вивчення споруд України від найдавніших часів до XIX ст., зокрема, дерев'яних культових. Охарактеризовано праці відомих фахівців тих років: Г. Павлуцького, Є. Рєдіна, О. Новицького, В. Щербаківського, М. Макаренка, Є. Сіцінського та інших авторів. Вивчення названої проблеми в цих наукових роботах засновано на аналізі численної інформації як результату системної роботи багатьох науковців й аматорів з дослідження творів архітектури. Визначено наукові ідеї дослідників щодо еволюції форм даної галузі образотворчості та обґрунтування унікальності української архітектури.

Висновки 6 Розглянуті матеріали дозволяють зробити висновок щодо поважного наукового рівня публікацій 1900-х рр. як вагомої 
складової формування наукових уявлень про національні риси вітчизняної архітектури. Такий високий дослідницький рівень сприяв становленню одного з провідних напрямків мистецтвознавства в Україні початку XX ст. Завдяки сукупності загальних соціокультурних та спеціальних чинників, подвижницькій діяльності ряду науковців дослідження в окресленій галузі впродовж десятиріччя досягають кількісно та якісно нового рівня. Зростає не лише обсяг інформації в даній сфері, але й вибудовується концепція національної самодостатності української архітектурної школи як повноправної складової міжнародного мистецького процесу. Оприлюднені матеріали обумовили плідний подальший розвиток розглянутих наукових ідей у наступних десятиліттях, що ознаменувалось утвердженням української науки про мистецтво в загальноєвропейському науковому просторі.

\section{Список бібліографічних посилань}

Волков, Ф.К. (1910). Старинные деревянные церкви на Волыни. В Ф. К. Волков (ред.), Материалы по этнографии России (Т. 1, с. 21-44). Этнографический отдел Русского музея Императора Александра III.

Горностаев, Ф. Ф. (1911). Строительство графов Разумовских в Черниговщине. В П. С. Уварова (ред.), Труды Четырнадцатого Археологического съезда в Чернигове 1908-1909 (Т. 2, с. 167-212). Типография Г. Лисснера и Д. Собко.

Заседание обществ. Общество Нестора Летописца при Университете св. Владимира. (1899). Киевская старина, 12, 168-172.

Карпович, В. (1905). Малороссийское церковное зодчество. Строитель, 10, 361-382.

Ковпаненко, Н. (2013). Архітектурно-мистецька спадщина Наддніпрянської України у вітчизняних історичних дослідженнях (кінець XIX - початок XX століття). Інститут історії України.

Константинович, М. (1896). Развалины Юрьевой божницы в с. Старогородке. Киевская старина, 11, 129-139.

Лагутенко, О. (2006). Українська графіка першої третини XX століття. Грані-Т.

Лашкарев, П. А. (1875). Киевская архитектура X-ХІІ века. Типография С.В. Кульженко.

Лашкарев, П. А. (1898). Церковно-археологические очерки, исследования и рефераты. Типография И.И. Чоколова.

Лебединцев, П. Г. (1878). О св. Софии Киевской. В В. И. Модестов (ред.), Труды Третьего археологического съезда в России, бывшего в Киеве в августе 1874 года (Т. 1, с. 5393). Типография Императорского Университета св. Владимира.

Лебединцев, П. Г. (1885). Киево-Михайловский Златоверхий монастырь в его прошедшем и настоящем. Типография С.В. Кульженко.

Макаренко, Н. (1908a). Памятники украинского искусства XVIII века. Зодчий, 24, 211-215.

Макаренко, Н. (1908b). Памятники украинского искусства XVIII века. (Окончание). Зодчий, 25, 219-222.

Новицкий, А. П. (1911). Черты самобытности в украинском зодчестве. В П. С. Уварова (ред.), Труды Четырнадцатого Археологического съезда в Чернигове 1908-1909 (Т. 2, с. 59-

72). Типография Г. Лисснера и Д. Собко.

Нога, О. (1997). Проект пам'ятника Івану Левинському. Українські технології. 
Павлуцкий, Г. Г. (1905). Древности Украины (Вып. 1: Деревянные и каменные храмы Украины). Типография С.В. Кульженко.

Павлуцкий, Г. Г. (1911). О происхождении форм украинского деревянного церковного зодчества. В П. С. Уварова (ред.), Труды Четырнадцатого Археологического съезда в Чернигове 1908-1909 (Т. 2, с. 47-58). Типография Г. Лисснера и Д. Собко.

Палієнко, М. Г. (2005а). «Кіевская старина» у громадському та науковому житті України (кінець XIX - початок XX століття). Темпора.

Палієнко, М. Г. (2005b). «Кіевская старина» (1882-1906): систематичний покажчик змісту журналу. Темпора.

Палієнко, М. Г. (2005с). «Кіевская старина» (1882-1906): хронологічний покажчик змісту журналу. Темпора.

Петров, Н. И. (1897). Историко-топографические очерки древнего Киева (с планом древнего Киева 1638 года). Типография Императорского Университета св. Владимира.

Побожій, С. І. (2005). З історії українського мистецтвознавства. Університетська книга.

Пучков, А. (2017). Григорій Павлуцький яко перший український мистецтвознавець, або Замкнений у часі просторовий образ архітектурознавства. В Г. Г. Павлуцький, Дерев'яні та муровані храми України (с. 7-24). Видавець Олександр Савчук.

Редин, Е. К. (1905). Церкви города Харькова. Материалы к изучению церковных древностей Украины. Печатное дело.

Сецинский, Е. (1907). Южно-русское церковное зодчество. Типография Подольского СвятоТроицкого Братства.

Филянский, Н. (1905). Наследие Украины. Очерк южнорусского народного творчества. Искусство, 3, 27-45.

Ханко, В. М. (1997). Ретроспективне зіставлення просторових рішень в українській архітектурі. Артанія, 3, 20-21.

Щербаковский, В. (1904). Квопросу отипахстаринныхмалорусскихцерквей. Археологическая летопись Южной России, 6, 232-235.

Щербаковський, В. (1906). Деревляні церкви на Україні та їх типи. В М. Грушевський (ред.), Записки наукового товариства імені Шевченка (Т. 74, кн. 6, с. 10-32). Товариство імені Шевченка.

\section{References}

Filyanskii, N. (1905). Nasledie Ukrainy. Ocherk yuzhnorusskogo narodnogo tvorchestva [Legacy of Ukraine. Sketch of the South Russian Folk Art]. Iskusstvo, 3, 27-45 [in Russian].

Gornostaev, F. F. (1911). Stroitel'stvo grafov Razumovskikh v Chernigovshchine [Construction of Counts Razumovsky in Chernihiv Region]. In P. S. Uvarova (Ed.), Trudy Chetyrnadtsatogo Arkheologicheskogo s»ezda v Chernigove 1908-1909 [Proceedings of the Fourteenth Archaeological Congress in Chernigov 1908-1909] (Vol. 2, pp. 167-212). G. Lissner and D. Sobko Publishing House [in Russian].

Karpovich, V. (1905). Malorossiiskoe tserkovnoe zodchestvo [Little Russian Church Architecture]. Stroitel', 10, 361-382 [in Russian].

Khanko, V. M. (1997). Retrospektyvne zistavlennia prostorovykh rishen v ukrainskii arkhitekturi [Retrospective Comparison of Spatial Solutions in Ukrainian Architecture]. Artaniia, 3, 20-21 [in Ukrainian].

Konstantinovich, M. (1896). Razvaliny Yur'evoi bozhnitsy v s. Starogorodke [The Ruins of St. George's Goddess in the Village Starogorodka]. Kievskaya starina, 11, 129-139 [in Russian].

Kovpanenko, N. (2013). Arkhitekturno-mystetska spadshchyna Naddniprianskoi Ukrainy u vitchyznianykh istorychnykh doslidzhenniakh (kinets XIX - pochatok XX stolittia) [Architectural and Artistic Heritage of Dnieper Ukraine in Domestic Historical Research (late $X I X$ - early XX Century)]. Instytut istorii Ukrainy [in Ukrainian]. 
Lahutenko, O. (2006). Ukrainska hrafika pershoi tretyny XX stolittia [Ukrainian Graphics of the First Third of the Twentieth Century]. Hrani-T [in Ukrainian].

Lashkarev, P. A. (1875). Kievskaya arkhitektura X-XII veka [Kiev Architecture of the X-XII Centuries]. S.V. Kul'zhenko Printing house [in Russian].

Lashkarev, P. A. (1898). Tserkovno-arkheologicheskie ocherki, issledovaniya i referaty [ChurchArchaeological Essays, Research and Abstracts]. I.I. Chokolov Printing house [in Russian].

Lebedintsev, P. G. (1878). O sv. Sofii Kievskoi [About St. Sofia Kievskaya]. In V. I. Modestov (Ed.), Trudy Tret'ego arkheologicheskogo s»ezda v Rossii, byvshego v Kieve $v$ avguste 1874 goda [Proceedings of the Third Archaeological Congress in Russia, which was in Kiev in August 1874] (Vol. 1, pp. 53-93). Tipografiya Imperatorskogo Universiteta sv. Vladimira [in Russian].

Lebedintsev, P. G. (1885). Kievo-Mikhailovskii Zlatoverkhii monastyr' $v$ ego proshedshem i nastoyashchem [Kyiv-Mikhailovsky Golden-Domed Monastery in its Past and Present]. S.V. Kul'zhenko Printing house [in Russian].

Makarenko, N. (1908a). Pamyatniki ukrainskogo iskusstva XVIII veka [Monuments of Ukrainian art of the 18th Century]. Zodchii, 24, 211-215 [in Russian].

Makarenko, N. (1908b). Pamyatniki ukrainskogo iskusstva XVIII veka. (Okonchanie) [Monuments of Ukrainian Art of the 18th Century. (Ending)]. Zodchii, 25, 219-222 [in Russian].

Noha, O. (1997). Proekt pamiatnyka Ivanu Levynskomu [Project of the Monument to Ivan Levynsky]. Ukrainski tekhnolohii [in Ukrainian].

Novitskii, A. P. (1911). Cherty samobytnosti v ukrainskom zodchestve [Identity Features in Ukrainian Architecture]. In P. S. Uvarova (Ed.), Trudy Chetyrnadtsatogo Arkheologicheskogo s'ezda v Chernigove 1908-1909 [Proceedings of the Fourteenth Archaeological Congress in Chernigov 1908-1909] (Vol. 2, pp. 59-72). G. Lissner and D. Sobko Publishing House [in Russian].

Paliienko, M. H. (2005a). "Kievskaia staryna" u hromadskomu ta naukovomu zhytti Ukrainy (kinets XIX - pochatok XX stolittia) ["Kievskaia staryna" in the Public and Scientific Life of Ukraine (late XIX - early XX Century)]. Tempora [in Ukrainian].

Paliienko, M. H. (2005b). "Kievskaia staryna" (1882-1906): systematychnyi pokazhchyk zmistu zhurnalu ["Kievskaia staryna" (1882-1906): a Systematic Index of the Contents of the Journal]. Tempora [in Ukrainian].

Paliienko, M. H. (2005c). "Kievskaia staryna" (1882-1906): khronolohichnyi pokazhchyk zmistu zhurnalu ["Kievskaia staryna" (1882-1906): a Chronological Index of the Contents of the Journal]. Tempora [in Ukrainian].

Pavlutskii, G. G. (1905). Drevnosti Ukrainy [Antiquities of Ukraine] (Issue 1: Derevyannye i kamennye khramy Ukrainy [Wooden and Stone Temples of Ukraine]). S.V. Kul'zhenko Printing house [in Russian].

Pavlutskii, G. G. (1911). O proiskhozhdenii form ukrainskogo derevyannogo tserkovnogo zodchestva [On the Origin of Forms of Ukrainian Wooden Church Architecture]. In P. S. Uvarova (Ed.), Trudy Chetyrnadtsatogo Arkheologicheskogo s'ezda v Chernigove 1908-1909 [Proceedings of the Fourteenth Archaeological Congress in Chernigov 1908-1909] (Vol. 2, pp. 47-58). G. Lissner and D. Sobko Publishing House [in Russian].

Petrov, N. I. (1897). Istoriko-topograficheskie ocherki drevnego Kieva (s planom drevnego Kieva 1638 goda) [Historical and Topographical Sketches of Ancient Kiev (With a Plan of Ancient Kiev in 1638)]. Tipografiya Imperatorskogo Universiteta sv. Vladimira [in Russian].

Pobozhii, S. I. (2005). Z istorii ukrainskoho mystetstvoznavstva [From the History of Ukrainian Art History]. Universytetska knyha [in Ukrainian].

Puchkov, A. (2017). Hryhorii Pavlutskyi yako pershyi ukrainskyi mystetstvoznavets, abo zamknenyi u chasi prostorovyi obraz arkhitekturoznavstva [Hryhorii Pavlutskyi as the First Ukrainian Art Critic, or a Time-Bound Spatial Image of Architectural Studies]. In H. H. Pavlutskyi, Dereviani ta murovani khramy Ukrainy [Wooden and Brick Temples of Ukraine] (pp. 7-24). Publisher Oleksandr Savchuk [in Ukrainian]. 
Redin, E. K. (1905). Tserkvi goroda Khar'kova. Materialy k izucheniyu tserkovnykh drevnostei Ukrainy [Churches of the City of Kharkov. Materials for the Study of Church Antiquities in Ukraine]. Pechatnoe delo [in Russian].

Setsinskii, E. (1907). Yuzhno-russkoe tserkovnoe zodchestvo [South Russian Church Architecture]. Tipografiya Podol'skogo Svyato-Troitskogo Bratstva [in Russian].

Shcherbakovskii, V. (1904). K voprosu o tipakh starinnykh malorusskikh tserkvei [On the Question of the Types of Old Little Russian Churches]. Arkheologicheskaya letopis' Yuzhnoi Rossii, 6, 232-235 [in Russian].

Shcherbakovskyi, V. (1906). Derevliani tserkvy na Ukraini ta yikh typy [Wooden Churches in Ukraine and their Types]. In M. Hrushevskyi (Ed.), Zapysky naukovoho tovarystva imeni Shevchenka [Notes of the Shevchenko Scientific Society] (Vol. 74, Book 6, pp. 10-32). Tovarystvo imeni Shevchenka [in Ukrainian].

Volkov, F. K. (1910). Starinnye derevyannye tserkvi na Volyni [Ancient Wooden Churches in Volyn]. In F. K. Volkov (Ed.), Materialy po etnografii Rossii [Materials on the Ethnography of Russia] (Vol. 1, pp. 21-44). Etnograficheskii otdel Russkogo muzeya Imperatora Aleksandra III [in Russian].

Zasedanie obshchestv. Obshchestvo Nestora Letopistsa pri Universitete sv. Vladimira [Meeting of Societies. Society of Nestor the Chronicler at the University of St. Vladimir]. (1899). Kievskaya starina, 12, 168-172 [in Russian]. 